\title{
連載講座
}

\section{ターポパスカルによるパーンナルコンピュータ入門 $(1)$}

\author{
太田隆 久 \\ (東京大学费学部限茲化学科)
}

\section{1. 中高年研究者へのパソコンのすすめ}

罘近は、どこの研究堂ですパーソナルコンピュータ(パ

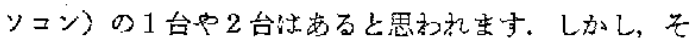

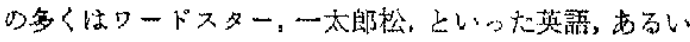
は日本語のワードプロセッサとして, 票たは, dBASEII, dBASEIII 等のデータベースプログラムの市骐のパッ ケージプログラム在使うくらいの役にしかたっていない のではないでしょらか．香ららん，物理，化学，工学方

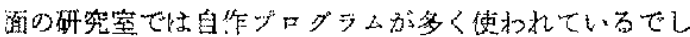
ょうし、学部，大学院の学生の上らな若い人たちは自宅

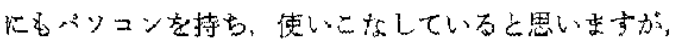

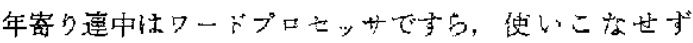

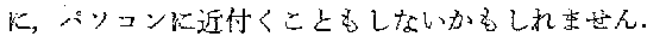

しかし，ハソコンは若者のための物ではなく私見によ

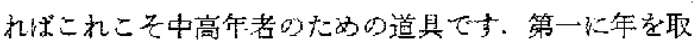

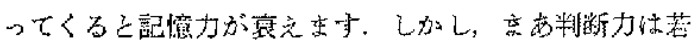
いものに角なな，い中，そ礼以のつもりてしょら.

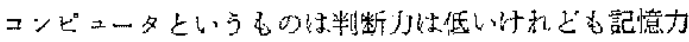

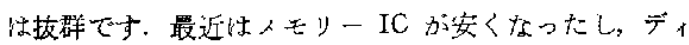

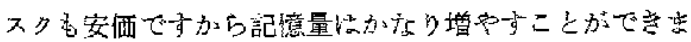

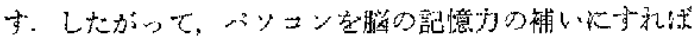
よいのてす，第二にこの解説で报うよらにプロダラムを

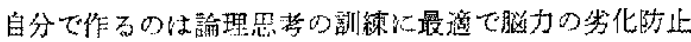

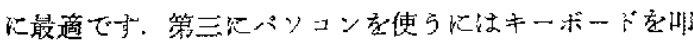

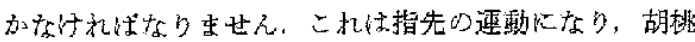

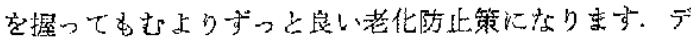
イスプレイモニターを兒つめることぐらいが慕点です

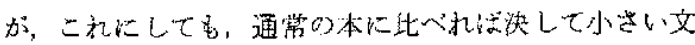

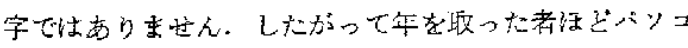

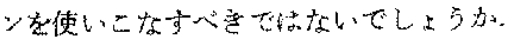

そこて，この講座は中高年研究者による中高年研究者 淎げるペンヌン入門のつるりで畫いたるのです。ここ

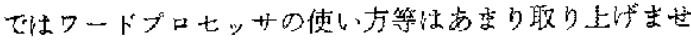
ル．自分でプログラムを作ってパソコンを使いこ放すこ

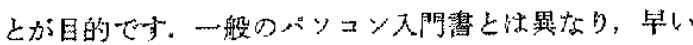
時期にディスタフォイル(後述)の取り极いを練㿟し

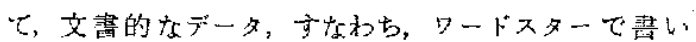

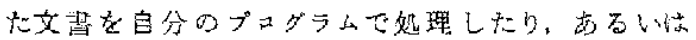
EMBL，GenBank，NBRF などの核酸，蛋白㗨配列デ 一ダを自分のブログラムと取り达文自分の詇理で解析寸 るといいた害用的プログラム（簡単なるのしか报いせ

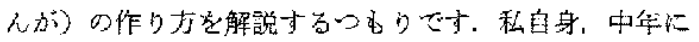

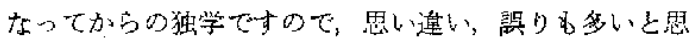

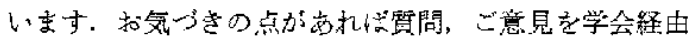
て必笴世下些い。

まず，ハンェン能れたことのない中高年研究者はパ

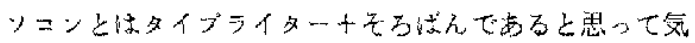

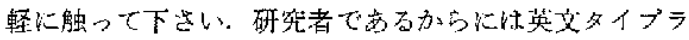

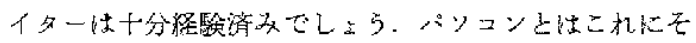

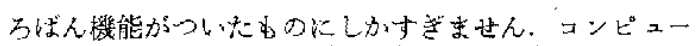
ターを動かす上はキーを咱くことによりパンコンに命令 して、をのそるばんを勳加こ上です。

この解説の丧題にあるターボハスカルという言葉に㢦 染多のないかか多いていょら。これ仿パンンと話すた

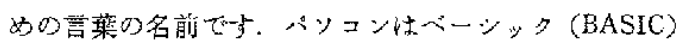
とい5ものを使うものと思っている人がかなりるのて

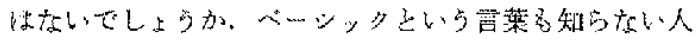

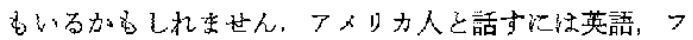
ランス人とならフランス語を使うのが自然てしょう。 れよ同しようにコンピュータと話すにはとれ滴した商 莱が必要なのです。このコンピュータ用の言語が、ーー

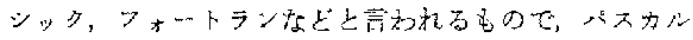

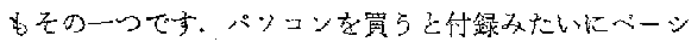
ックが付いてくるのでれ在使ら人が多いのですか，実

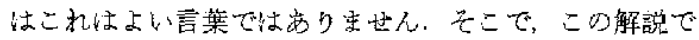

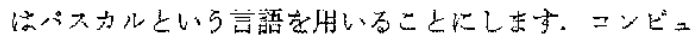

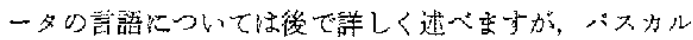
はプロダラミングの教育用恶語として開発されたものて

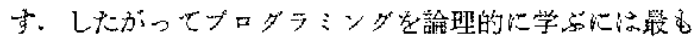
適した言菜上い党焉。研究者心はベーシック上り姑す゚ っ上適しているるのです。た，ハーソナルョンビュー

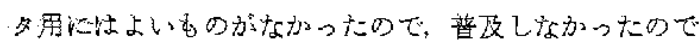


すが，最近，米国の Borland International 社からター

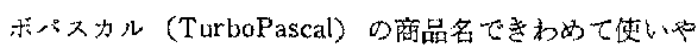
ナいあのが発売されました。 そこで,このターボバスカ ルを用いて解説をすることにしました。

また，解説の都合上，パンコソ機種を NEC の PC 9801 シリーズを中心化しすが，後述する上万名一

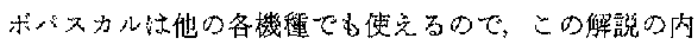

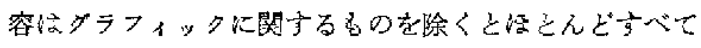

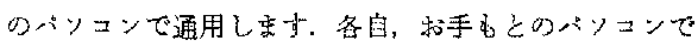
試してくたさい，ターボパスカル等の入手の方法等につ いては後で连心゙す。

\section{2. パーソナルコンピュータの原理}

(1) ハーソナルコンビュータの橉成

PC 9801 シリーズのコンピュータは大体图 1 に示少よ

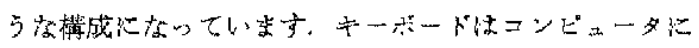

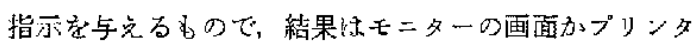
一に表示されます、フロッピーディスタドライブにはフ ロッピーディスク（ディスクと略称する）と呼ばれるる のが差し込まれてプログラムやデータの受漠しが行私 生す、ディスクを入れずにバワースイッチ存入れな場合 には内蔵されているペーシック言語が作動するよらにな ってい李。操作てついては後述します。

(2) パーソナルコンピュータの原理

ワードプロセッサなどはパーソナルコンピュータの原

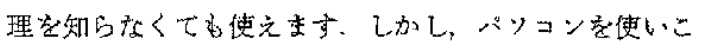

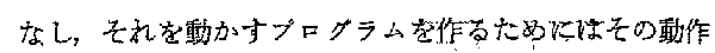

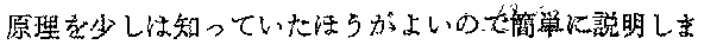
文.

图 2 は図 1 を内容的に書き直したものです。ここに は，電源など訬一切省路し，機能的な部分の概略だけ示 してあります、图1のコンピュータ本体の中は括括さ

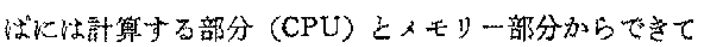
いせす。

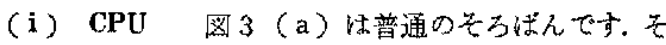
ろばんを使って計算する上きはそるばん上のある場所で 計算 Lて，他の場所火演算梌中の值を一時的淔くこと があり京可。先飞，ハンコンをタイプライター+そるば んと蟙きむしたが，图2の CPU (Central Processing

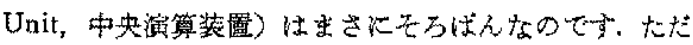

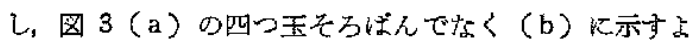

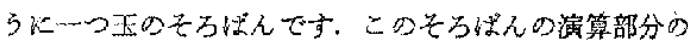
桁数は PC 9801 などで治 16 标, PC 8801 などで 8 桁です。この演算部分で数の加隇，比較等を行うのはコ ンピニータの許算なのです。溜算中の数を記億したり， 8，西いい 16 桁以上の桁上がり，桁下がりの有無を

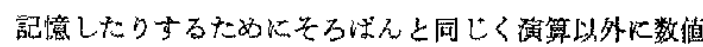
を置いておく部分等がありこれらを含んだ計算摮置が

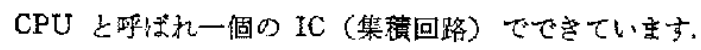
一つ玉ですから五の上下だけしかできす，一桁往０，1 の2 值のみを表すので，2進法で，一つの桁を binary unit, 略してビット（bit）と呼びます．普通のそるばん

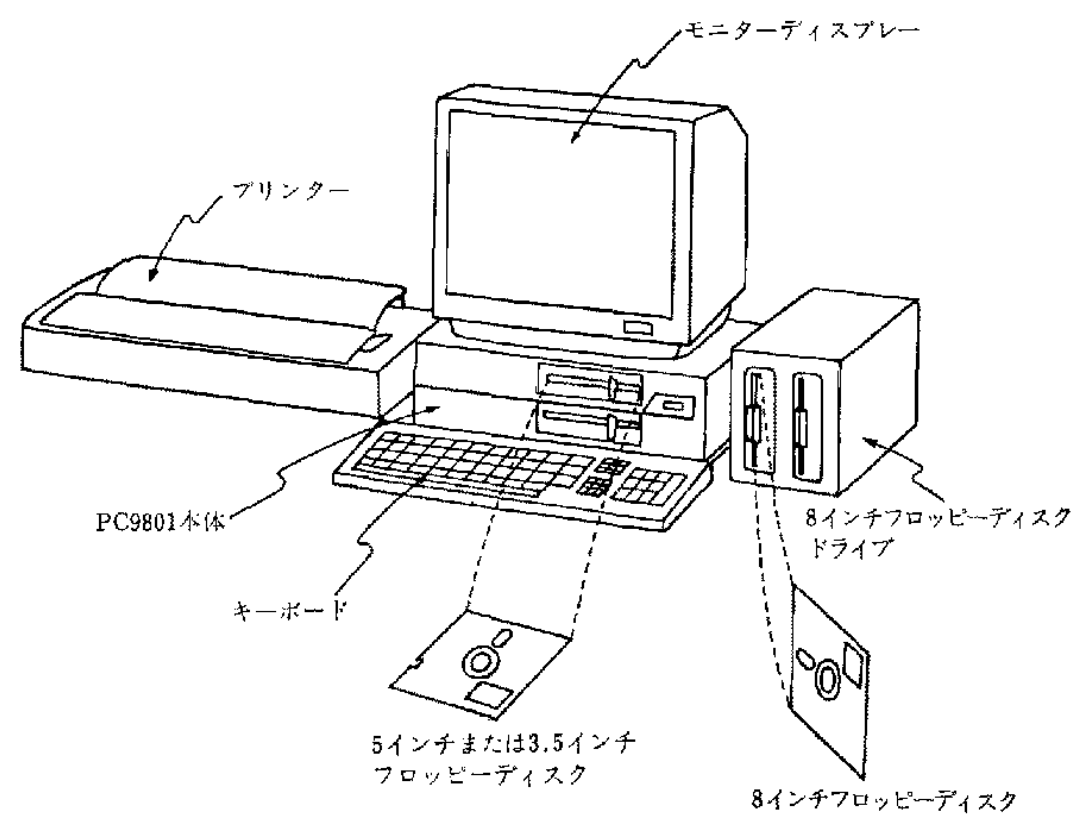

图 1 パーソナルロソピュータの概観 


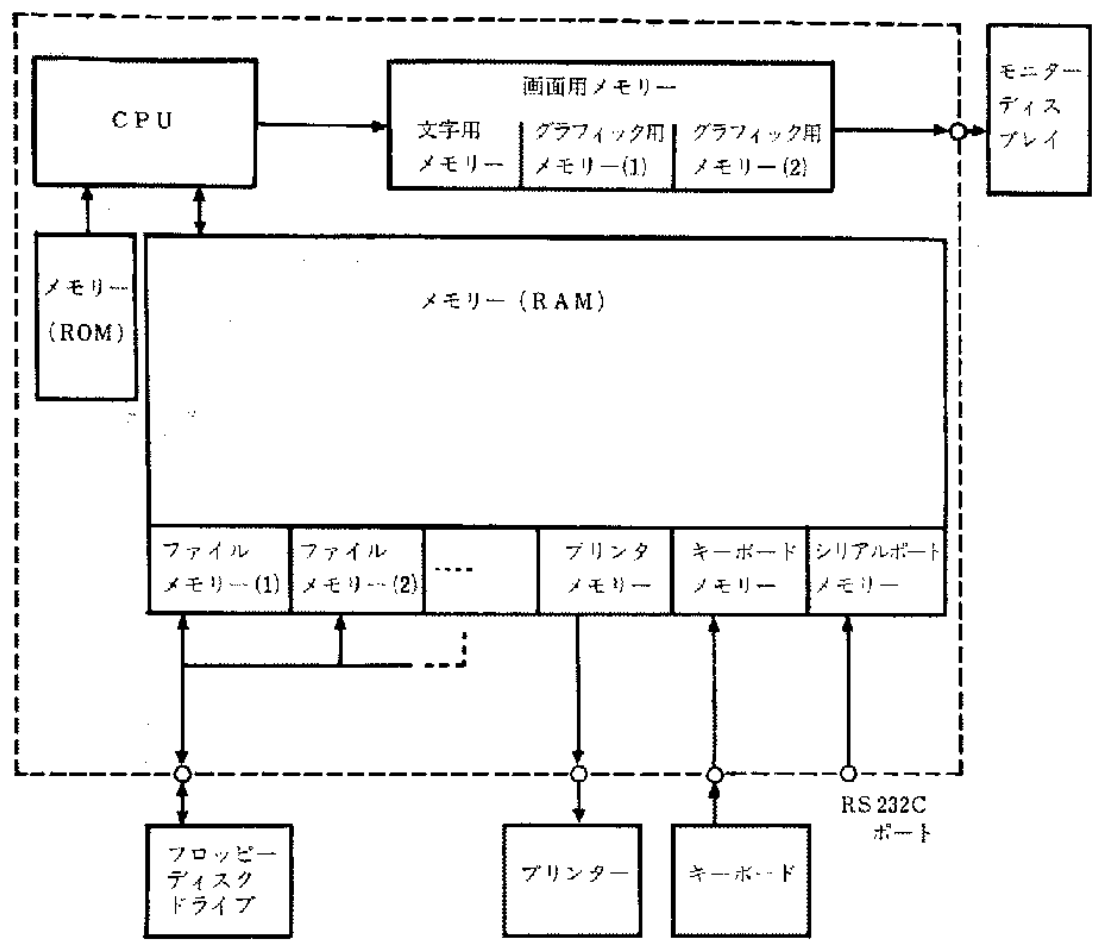

图 2 パーソナルコンピュータの内部

(a) 薏通のでらばん

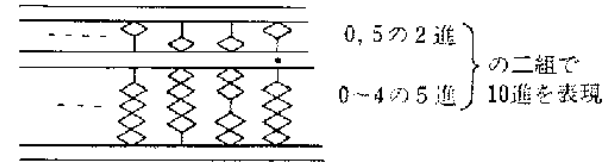

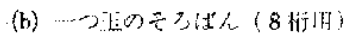

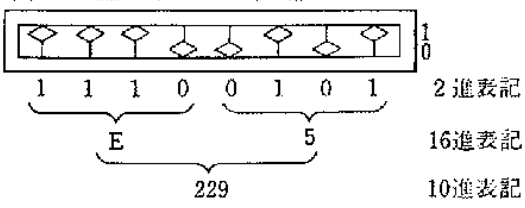

(c) CPU ( 8 ど\% ト)

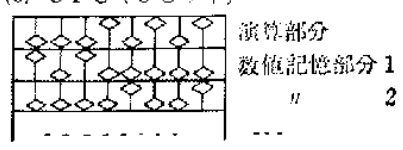

(d) $x \neq 1-$

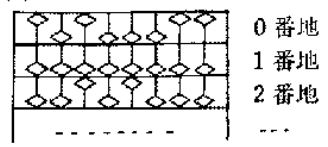

图 3 コンピューダ演算の穱念

は 5 進と 2 進の組合せで 10 進の計算を行っているわけ です. (c) の8桁のるあ8ピットの CPU といい, PC8801 は8ビットのパソコンに分類されるす. 8 桁机

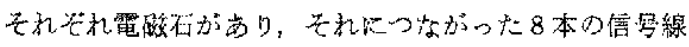

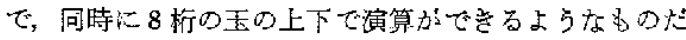

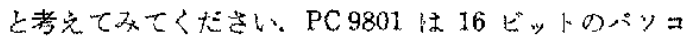

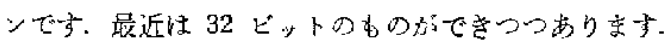
8 ビットでは， $2^{8}=256$ 㛾の数 (0から255まで) 。 16 とッなでは, $2^{16}=65536$ の数（0から65535まで) を一度に报名るため, 16 ビット機の忹らが性能がよいの

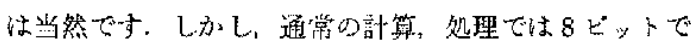
も十分閪に合うので PC 8801 む夷用沈なります。

(ii) 16 進数 前節でロンピュータが原理的に2 進法で計算されると書さ机した８ビットで表すことの できる值法2 進法で書くと00000000 から11111111にな

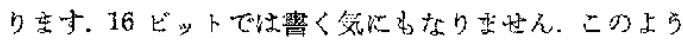
に2進法で表すと人問にとって茪にくいので䘚現法を工

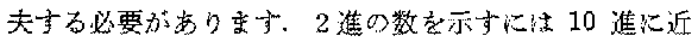

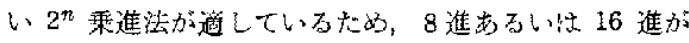
よく用いられます，16 准法では 10 谁の10 から15 に 対底奇記号がないので，一析の数としてAからFまて

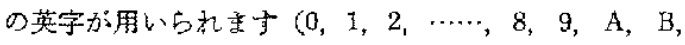
C, D, E, F よなる). したがって、10 進数の 10 は 16 進数では A, 255 は FF です $(15 \times 16+15) .16$ 進

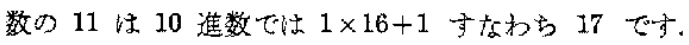
混京避けるためにターボパスカルでは 16 進数には 
前にあるつけます。したか゚って，\$11=17といらことに なり立す. 4 ビットが\$0がら\$Fの数效応し，8ビ

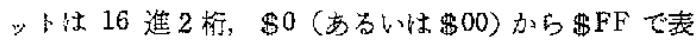

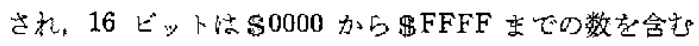
ことが出来东す，10 進数で畫くより，2 准の構造を把握 しやすいのでュンピュータに直接関系する数仕しばしば

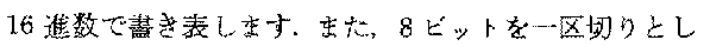

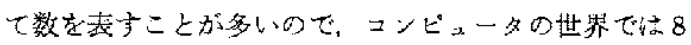
ビットで表すことのできるのから255までの数を1ハ 1ト（byte）という単位で表します。したがって，16 ビ

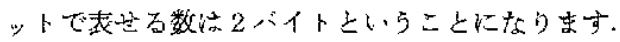

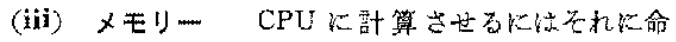
命を与克なければなりませんしテデータ等記譩させる

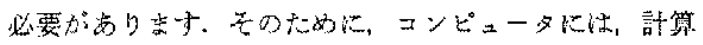
を行うCPU以外化数を敦億させて特くところが必要で 子。こ机かモりーで，CPU と同様に IC で出来てい

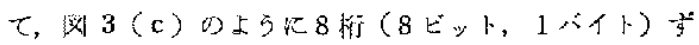

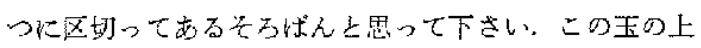

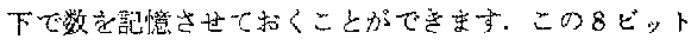

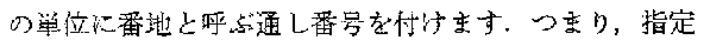

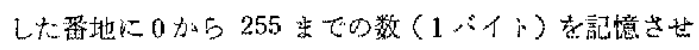

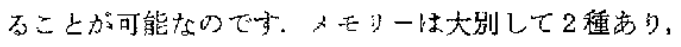
RAM (Random Access Memory, 読双畫害可能みもり 一) とROM (Read Only Memory，読灭取り専用丸七

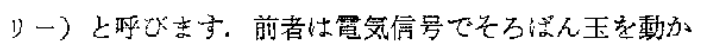

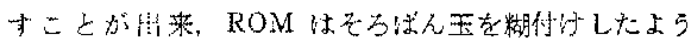
なもので值を変るることができないと考文て下さい。

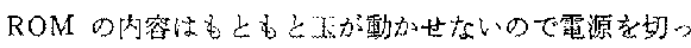
て娄保存され要すか，RAM 上の值坆電源を切るとすべ て消元てしまいます。生たは，RAM は通し番号付の升 目の人った電子黑板で 1 做の升日には1 バト 255，\$00 かららFF) の数を畫いたり消したりでき, 電

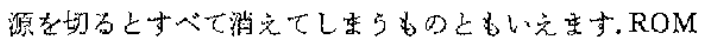
はこの舟目にインタであらかじ数が印刷されて和り。

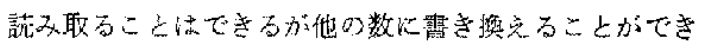
ない出のに效応し弯す。

(iv) フロッピーディスク RAM の内容は電源を 邚ると消光てしまいます。このため，プログラムやデー 夕索保存一るには，他にその内容を記録できるむのが必

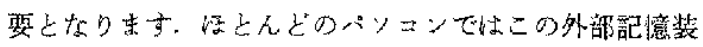
置として、フロッピーディスク (lloppy disc) 上称する 磁気模をコーティンクしホプラスティック繁の漂い内盤

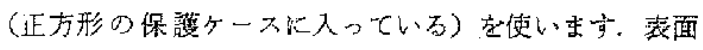

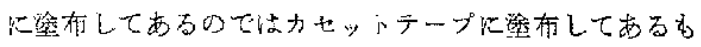
のた類似した磁性体でカセッ:テ・プが録音，録画した
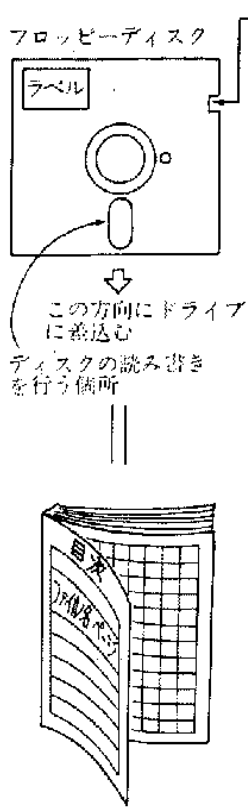

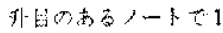

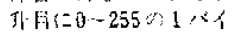

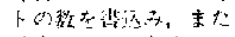

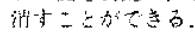

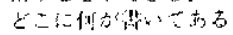

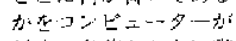

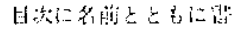
int.

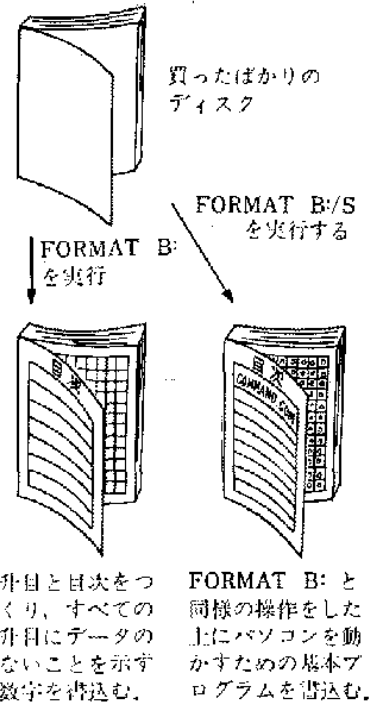

圈 4 フロッピーディスク

り，消去できるのと同滰记記録、消去ができるのです。

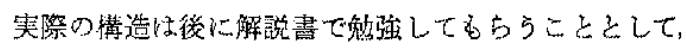
嘅念としては, ディスクは一種のノートブック代と思っ て下さい，図4 亿示す上らに原稿用紙の上5に升目があ り，何ぺージの何番目の升目に0から255まで数を

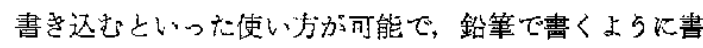
き达んだり，消しゴムで消すように消すことがでるる 思觉ぱよいのです。

ただし，筫ってきたばかりのディスク性白紙のノート で、このままでは青き込む埸所が指䇥されていないので

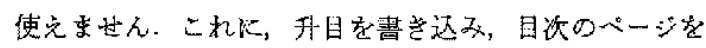

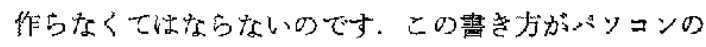
譏種によって買なり，通常フォーマット (format) と㭔

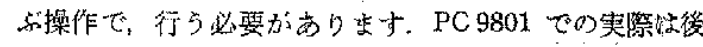
で述べます。

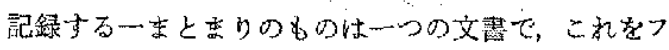

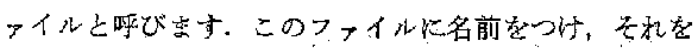
昌次 (ディレクトリ， directory）炕書焉、ベージその他 のデータを甾いて招くことにより目次から実際のデータ 


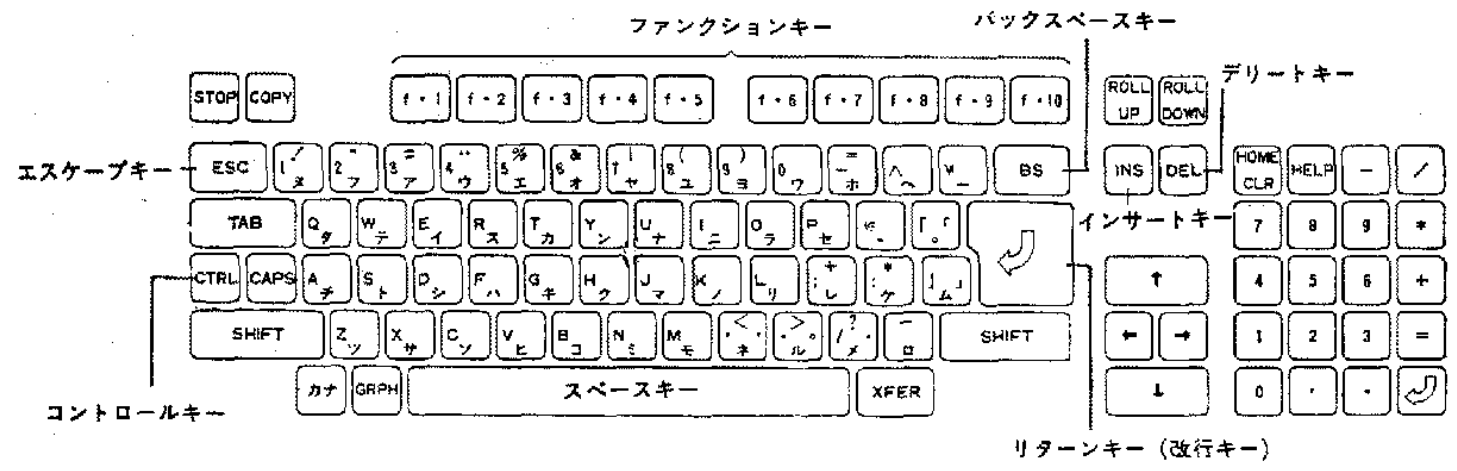

图 $5 \neq ー$ ー゙ード

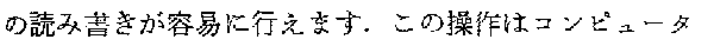
が行5ので，ペンンの操作たでは，ファイルの名前を

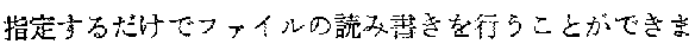
के.

RAM がコンピュータ内部のネモりーでディス怔

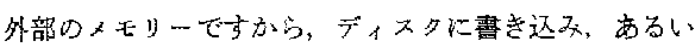
はティスクから谠及取るの保コンピュータのメ毛り(RAM)とのデータのやり取りになります。この橋渡し

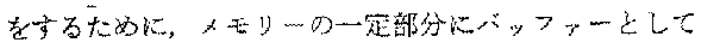

のメモり一領域を作り，RAMをディス少との間で、い ったん,ここにデータの一缡索移して、データのやり取 りを主ると考充ておいて下さい。

(v) モニターティスプレイ コンピッータからの

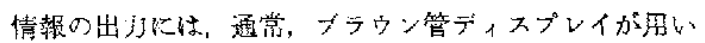
り礼ます。. PC 9801 では英数字、カナは1行 80 文字 25 行, 日本語は 1 行 40 文字 25 行, グラフィックは

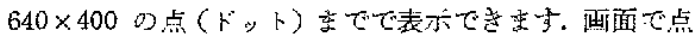

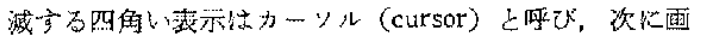

\begin{tabular}{|c|c|c|c|c|c|c|c|c|c|c|c|c|}
\hline $\begin{array}{c}16 \\
\text { 進致 }\end{array}$ & $\begin{array}{l}10 \\
\text { 進数 }\end{array}$ & $\begin{array}{l}\text { 文字 } \\
\text { 跑只 }\end{array}$ & $\begin{array}{l}\text { 制微 } \\
\text { 歌裳 }\end{array}$ & $\begin{array}{c}16 \\
\text { 槐数 }\end{array}$ & $\begin{array}{c}10 \\
\text { 谁好 }\end{array}$ & $\begin{array}{l}\text { 文字 } \\
\text { 祀号 }\end{array}$ & $\begin{array}{c}16 \\
\text { 恖数 }\end{array}$ & $\begin{array}{l}10 \\
\text { 准数 }\end{array}$ & $\begin{array}{l}\text { 文宗 } \\
\text { 觖昜 }\end{array}$ & $\begin{array}{c}16 \\
\text { 進努 }\end{array}$ & $\begin{array}{c}\text { 1. } 0 \\
\text { 傮数 }\end{array}$ & $\begin{array}{l}\text { 文等 } \\
\text { 虽号 }\end{array}$ \\
\hline 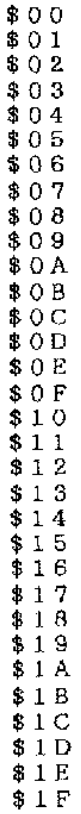 & $\begin{array}{ll} & 0 \\
1 \\
2 \\
3 \\
4 \\
5 \\
6 \\
7 \\
8 \\
9 \\
1 & 0 \\
1 & 1 \\
1 & 2 \\
1 & 3 \\
1 & 4 \\
1 & 5 \\
1 & 6 \\
1 & 7 \\
1 & 8 \\
1 & 9 \\
2 & 0 \\
2 & 1 \\
2 & 2 \\
2 & 3 \\
2 & 4 \\
2 & 5 \\
2 & 6 \\
2 & 7 \\
2 & 8 \\
2 & 9 \\
3 & 0 \\
3 & 1\end{array}$ & 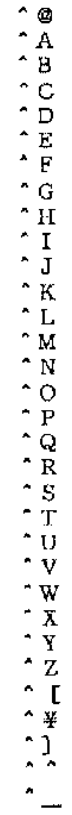 & $\begin{array}{l}\text { BE L } \\
\text { BS } \\
\text { HT } \\
\text { LF } \\
\text { VT } \\
\text { FF } \\
\text { CR }\end{array}$ & $\begin{array}{l}\$ 20 \\
\$ 21 \\
\$ 22 \\
\$ 23 \\
\$ 24 \\
\$ 25 \\
\$ 25 \\
\$ 27 \\
\$ 2 B \\
\$ 29 \\
\$ 2 A \\
\$ 2 B \\
\$ 2 C \\
\$ 2 D \\
\$ 2 E \\
\$ 2 F \\
\$ 30 \\
\$ 31 \\
\$ 32 \\
\$ 33 \\
\$ 34 \\
\$ 35 \\
\$ 36 \\
\$ 37 \\
\$ 38 \\
\$ 39 \\
\$ 3 A \\
\$ 3 B \\
\$ 3 C \\
\$ 3 D \\
\$ 3 E \\
\$ 3 F\end{array}$ & $\begin{array}{ll}3 & 2 \\
3 & 3 \\
3 & 4 \\
3 & 5 \\
3 & 6 \\
3 & 7 \\
3 & 8 \\
3 & 9 \\
4 & 0 \\
4 & 1 \\
4 & 2 \\
4 & 3 \\
4 & 4 \\
4 & 5 \\
4 & 6 \\
4 & 7 \\
4 & 8 \\
4 & 9 \\
5 & 0 \\
5 & 1 \\
5 & 2 \\
5 & 3 \\
5 & 4 \\
5 & 5 \\
5 & 6 \\
5 & 7 \\
5 & 8 \\
5 & 9 \\
6 & 0 \\
6 & 1 \\
6 & 2 \\
6 & 3\end{array}$ & 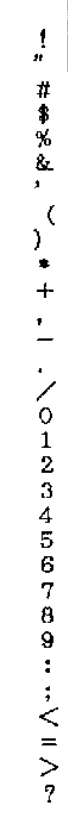 & $\begin{array}{l}\$ 40 \\
\$ 41 \\
\$ 42 \\
\$ 43 \\
\$ 44 \\
\$ 45 \\
\$ 46 \\
\$ 47 \\
\$ 48 \\
\$ 49 \\
\$ 4 A \\
\$ 4 B \\
\$ 4 C \\
\$ 4 D \\
\$ 4 \mathrm{E} \\
\$ 4 \mathrm{~F} \\
\$ 50 \\
\$ 51 \\
\$ 52 \\
\$ 53 \\
\$ 54 \\
\$ 55 \\
\$ 56 \\
\$ 57 \\
\$ 58 \\
\$ 59 \\
\$ 5 \mathrm{~A} \\
\$ 5 \mathrm{~B} \\
\$ 5 \mathrm{C} \\
\$ 5 \mathrm{D} \\
\$ 5 \mathrm{E} \\
\$ 5 \mathrm{~F}\end{array}$ & 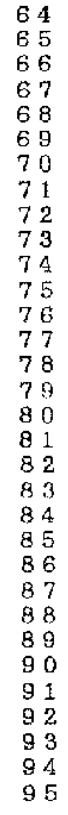 & 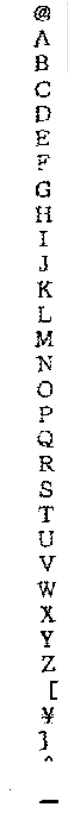 & $\begin{array}{l}\$ 60 \\
\$ 61 \\
\$ 62 \\
\$ 63 \\
\$ 64 \\
\$ 65 \\
\$ 66 \\
\$ 67 \\
\$ 68 \\
\$ 69 \\
\$ 61 \\
\$ 6 \mathrm{~B} \\
\$ 6 \mathrm{C} \\
\$ 6 \mathrm{D} \\
\$ 6 \mathrm{E} \\
\$ 6 \mathrm{~F} \\
\$ 70 \\
\$ 71 \\
\$ 72 \\
\$ 73 \\
\$ 74 \\
\$ 75 \\
\$ 76 \\
\$ 77 \\
\$ 78 \\
\$ 79 \\
\$ 7 \mathrm{~A} \\
\$ 7 \mathrm{~B} \\
\$ 7 \mathrm{C} \\
\$ 7 \mathrm{D} \\
\$ 7 \mathrm{E} \\
\$ 7 \mathrm{~F}\end{array}$ & 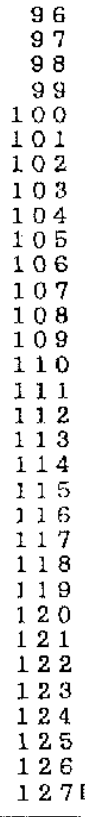 & 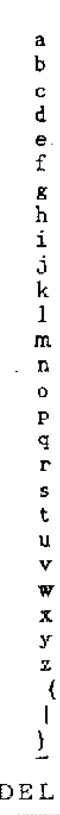 \\
\hline
\end{tabular}

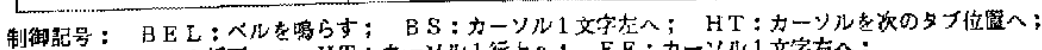
LF：カーソル1行下； VT:カーソル1行上八； F F :カーソル1文家右へ；

LF: SUB: 画面りリア； ESC：エスケープコード、ESCキーと闻し；

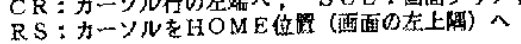

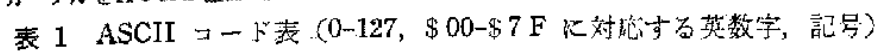


面に文字が表示される場所を示します．モニター化表示

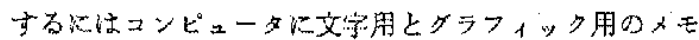

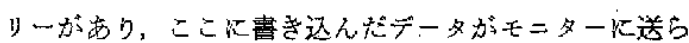
机表示さ机ます。

(vi) キーボート キーボードはコンピニータに入

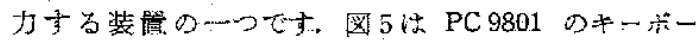

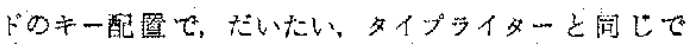

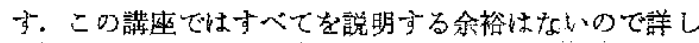
く汇説明書を管んでもららこととして，必要な部分だ

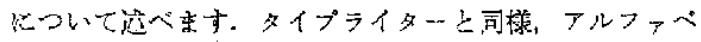

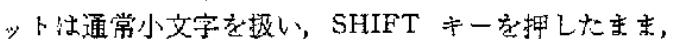
英数字のキーを押せば大文字括よび記号の入うができま 坊，CAPS キーはタイ゚ライターの Lockキーのよう

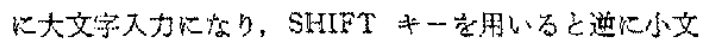

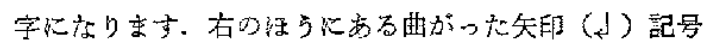
のキーは夕イブライターのRETURNキーにあたり，二 ンピュータへの1行分の入力す名たるに使います。比 がって，普通の使い方で惊，このキーを押すまていュン ビ:ータにキーボードかららのデータ统入りませんから，

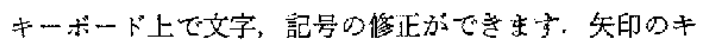

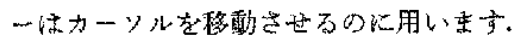

(vii) プリンー モ二ター上の表示はすく消充 てしまらので，女字，記号，グラフィックイスージはプ リンターに出力させて記録します。パソニン用のプリン

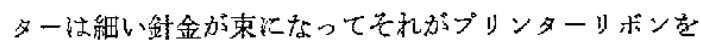
打つことによって卵孛するトットプリンターが多く使和 れてい、亲. ドットの数により印字の什上がりが異在

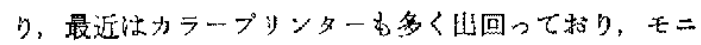
ターでのイメージカラーでプリントできます通常, データはィモリー上飞一行分が眝えられてプリターに 遂占れま主。

(viii) ASCII コード 今までパンュンでは 8，

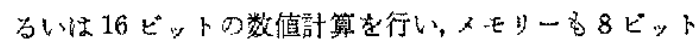
単位である述べてきましたををらするとキーボートか

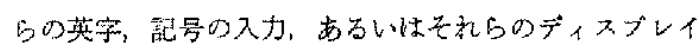

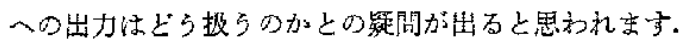

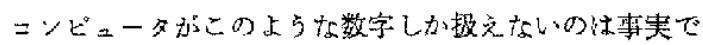
寸.そこで, ニンピュータでは文字, 塥号むこれら数字 で麦すことルするのてす、表1に ASCII コード表を載

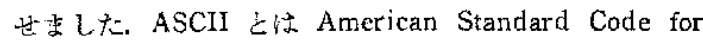
Information Interchange の路称で文学, 記号を数字工

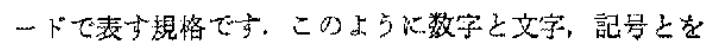

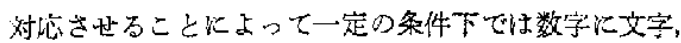
記号としての意味をむたせることができるのです，英文 タイブライター上の文記岩は 128 䑶以下である
で0から127(\$00がら\$7F)までの7ビット(2淮 法で00000000加 01111111) て表すことがで委す。

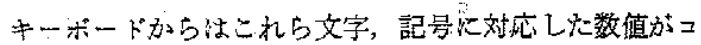
ンピニータ本体に送られ，コンピューダキーボード

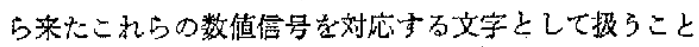
になります。これが ASCII コードといかれるもので

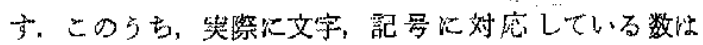

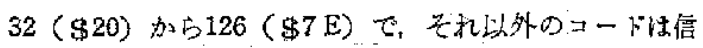
号の制御用（た之党ば文字や記号の消去，改行，へルの

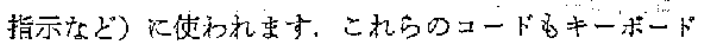
から入力寸ることができて、たとえば，127（\$7F)は

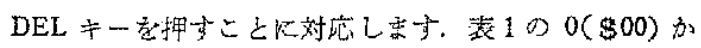

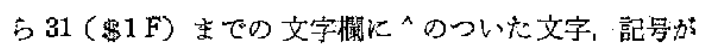

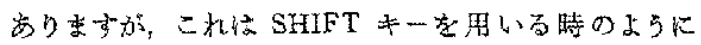

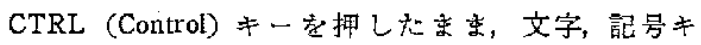

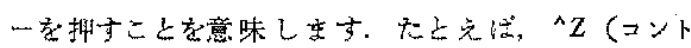

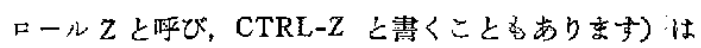

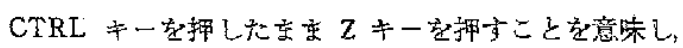
26 (\$1A) の数值肪キーポート加ら送与机ます。 2 進 数で忟 $\mathrm{Z}(\$ 1 \mathrm{~A})=00011010$ で, $Z(\$ 5 \mathrm{~A})=01011010$

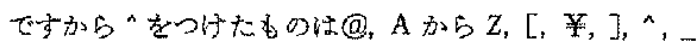

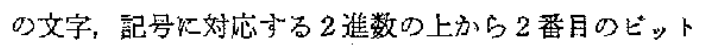
の1を0にした娄のになるかけです.

日本語で片仮名を报らため ASCII コードを捴㖘し て，\$80から\$FF虫での一番上のどットル1のあるュ

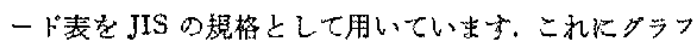
イック記昂など努付加して各機種用のコードが構成され

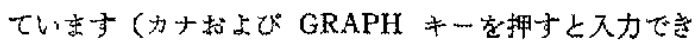
る). PC 9801 のキャラクターュード表はマニュアルを 見てください，漠字は1バイトては表せないので2パイ トのコードが JIS で決められてい亦。

このようなコードを累いれば、キーボードから文字、

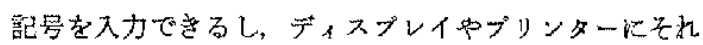
らを出力させることがでさます。が，いす゚れにして b実際にコンビュー夕內部では数字しが报われていない ことを理解して下さい。

(ix) ハードレンフト 以上述べてきた CPU， な

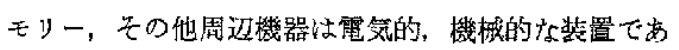

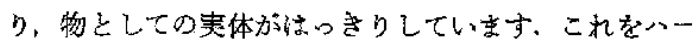
ドウェア (hardware)，略してハードと呼ずます，通常 の機械と異なり、コンと゚ュータは CPUに命令を与えな

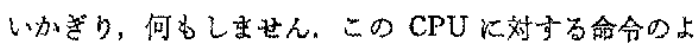
うな一連の指示, 要るいはデータ忙論理的概念, 文字的 な記録でらり，機械のよらな物理的実体を持たないるの です. これをシフトウェフ (software), 略してンフト 
と呼びます.プログラムをンフトと间意語のように用い

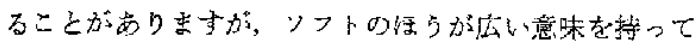
いすす。

(x) パーソナルコンピュー夕の勳作 多くのパ ソヌンでは図 2 ROM の一部 (IPL, Initial Program

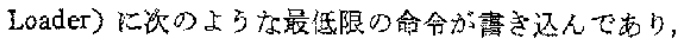

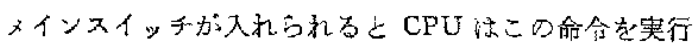

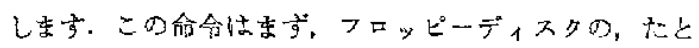

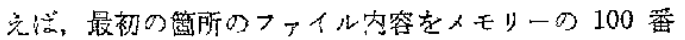

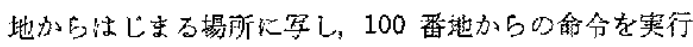
するとい的内容です。しがって、ディスクの最初の

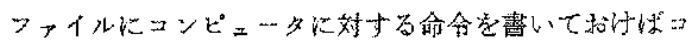

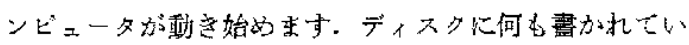
ない無限炕ディス多の内容を㨐し続计るか、ニラー表

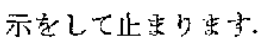

$(\infty-3)$

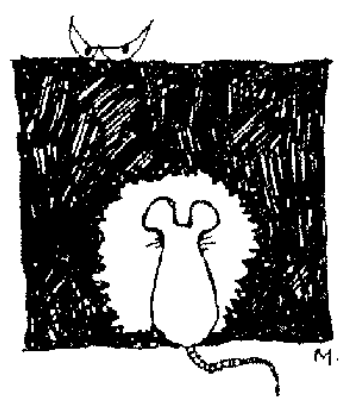

